\title{
German consumer evaluations of milk in blind and nonblind tests
}

\author{
Svetlana Kresova, ${ }^{1 *}{ }^{*}$ Daijana Gutjahr, ${ }^{2}$ () and Sebastian Hess ${ }^{1} \oplus$ \\ ${ }^{1}$ Department of Agricultural Policy and Markets, University of Hohenheim, Stuttgart, Germany 70599 \\ ${ }^{2}$ Department of Agricultural Economics, Christian-Albrechts-University of Kiel, Kiel, Germany 24118
}

\begin{abstract}
Greater differentiation is being made between types of milk according to product and process characteristics. This study investigated consumer preferences for 4 different types of milk in packaging-blind and nonblind experiments. The taste of long-life milk, conventional fresh whole milk, pasture-based milk, and organic milk was assessed by 138 randomly selected respondents. The average taste of packaging-blind versus nonblind milk types was statistically significantly different for each of the 4 milk types. Consumers appeared to be influenced by the milk's packaging and related credence-good attributes. It is noteworthy that the taste of organic milk during the blind tasting was given a lower rating, and the taste of long-life milk or UHT milk a higher rating, than when respondents were aware of the respective milk types. The study estimated multilevel mixedeffects logistic regression models with the response variable buying decision. Of all the factors studied in the blind and nonblind tasting of almost all milk types, buying decisions were influenced most by taste, overall assessment and income.
\end{abstract}

Key words: milk tasting, preference, credence-good attribute, differentiation

\section{INTRODUCTION}

In Germany's fresh milk retail market, dairy processors are increasingly marketing milk according to certain product and process characteristics. For farmers, this can imply higher revenues if certain consumer groups pay more for certain milk types, but the provision of certain process characteristics may increase production costs. This is particularly the case for organic milk versus conventional milk. Furthermore, conventional milk is increasingly being distinguished on the German market by whether cows have access to pasture for a specified number of days or are primarily kept indoors.

Received May 7, 2021

Accepted December 21, 2021.

*Corresponding author: skresova@gmail.com
The production of pasture-based milk is more expensive than conventional milk (Kühl et al., 2017).

If farmers can provide access to pasture at a reasonable cost, some dairy processors have previously paid price premiums to farmers and marketed this conventional milk as pasture-based milk, which may appear more "natural" than regular conventional milk. However, it is not clear whether pasture-based milk actually tastes different or whether consumers are primarily paying for its associated animal welfare aspect. Kühl et al. (2017) found in an online survey (without actual taste experiment) that consumers stated to prefer pasture milk because of taste and health value. This is particularly questionable given that access to pasture is typically not provided year-round, but only during the grassland vegetation season, which in Germany is usually from May to October.

Furthermore, organic milk in Germany continues to enjoy relatively high market prices, and living conditions for these cows differ from those of conventional dairy cows in many respects. Most importantly, dairy cattle nutrition on organic farms is primarily farmbased roughage, whereas conventional dairy cows are typically fed a much higher share of compound feed, including protein crops such as soy meal that are typically imported. The consumers strongly believe that organic milk is healthier, which also motivates them to purchase organic milk (Harwood and Drake, 2018).

Milk processing is also an important criterion for buying decisions for different types of milk. In terms of processing characteristics, a distinction is made with conventional milk in Germany between fresh (but pasteurized) and UHT milk, which has an extended shelf life due to sterilization and homogenization. The average retail price of UHT milk is typically below (Bimbo et al., 2016) that of conventional fresh milk, and it makes up the largest segment in the German milk market. However, due to the UHT process, this type of milk potentially has a slightly different protein structure. In addition, the practices of aseptical filling and storing at room temperature may also induce taste differences. The UHT treatment of milk is conducted at 135 to $154^{\circ} \mathrm{C}$ for 1 to $8 \mathrm{~s}$ (Penfield and Campbell, 1990). 
However, due to this treatment, UHT milk can have off-flavors, such as cooked, bitter, sweet, and stale notes (Hill, 1988). After processing, the UHT milk is usually stored for a longer time. During this storage process, the casein dissociation and whey protein or $\kappa$-CN association take place, and this is more pronounced in UHT milk (Liu et al., 2019). The sensorial properties of the final product of UHT milk are a function of (1) the level of the raw milk quality, (2) processing, and (3) storage time and conditions (Rosenberg, 2022). Traditional UHT systems may lead to even more pronounced changes in taste (Chavan et al., 2016).

How consumers choose in the store depends on psychological, sensory, and marketing factors (Kim et al., 2013). To understand the development of the market for fluid milk, consumers' perceptions of milk remain yet far from fully understood (Delley and Brunner, 2020).

The present study is organized as follows: after a brief summary of previous milk taste experiments, the experimental setup and the sampling strategy used in the study are explained, before the results are presented and discussed. Conclusions are then drawn that are of relevance for dairy product management and consumer decision-making.

This study analyzed if and to what extent a sample of randomly selected consumers distinguishes between these 4 types of milk by their taste and overall assessment, if and to what extent the additional presence of the corresponding milk packaging alters their preference assessments, and if and to what extent credencegood attributes and brand influence their buying decisions. The findings will improve understanding of the increasing product differentiation in the German fresh milk market. Are buying decisions primarily driven by credence-good attributes such as organic or pasturebased versus conventional, or is there any evidence that experience-related product attributes may to an extent also explain buying decisions? The study objective is to find out how respondents evaluate the taste of different types of fresh milk in blind and nonblind tests, and which factors influence related buying decisions for the milk types.

\section{MATERIALS AND METHODS}

Table 1 presents selected earlier studies on milk tasting experiments and surveys that were conducted by various researchers between 1966 and 2020. Table 1 aims to present an overview and comparison of the studies referenced therein. These studies have a somewhat comparable methodological approach as the present study. Other food preference tests generally investigate preferences with regard to the attractiveness of product characteristics for different consumers (Liming, 1966; Chung, 2009). If a particular milk type has better properties (e.g., taste), then the producing dairy company has more chances of being more successful than its competitors (Chimboza and Mutandwa, 2007). Testing of preferred milk characteristics may lead to more competitive product market introductions (Delarue et al., 2014). In addition, food taste experiments may allow spatial and temporal variations in milk preferences to be tested (Chang et al., 2011) and knowledge derived about the preferences of specific target groups (Ghose and Lowengart, 2001).

Four different types of whole milk were presented in the present study to 138 randomly selected respondents in walk-by experiments: long-life milk (UHT), pasturebased milk, organic milk, and conventional fresh whole milk. All the milk samples were whole milk types with a fat content of 3.5 to $3.9 \%$ (long-life milk from Weihenstephan: $3.5 \%$ fat; pasture milk from Hansano: $3.9 \%$ fat; organic milk from Hamfelder Hof: $3.8 \%$ fat; and fresh whole milk from Horst: $3.5 \%$ fat). Pasture-based milk and organic milk were extended shelf life (ESL) milks, fresh conventional milk was HTST pasteurized milk, and long-life milk was UHT milk. The present paper takes UHT milk as the base and compares it with conventional pasteurized milk, pasture-based conventional milk, and organic milk. This study adopted the walk-by interview approach with blind and nonblind tasting to investigate the milk packaging's relative effect with fresh milk types that have different attributes.

In addition, Figure 1 summarizes experimental setup of the present study and visualizes the main steps of tasting process with walk-by participants. The experimental design of the study can be described as follows: the milk was served to respondents in transparent 50-mL plastic cups marked with stickers that showed randomly assigned 3-digit numbers. In a separately prepared table that was hidden from respondents, each of these numbers corresponded to the specific milk type used for the blinded tests. For nonblinded tests, the milk was served in transparent $50-\mathrm{mL}$ plastic cups marked with stickers that indicated the type of the milk. In addition, during the nonblind tasting, the packages of milk were presented to the participants next to the plastic cups, so that they could inform themselves about milk content, production place, and brand. Also, the participants could ask the researchers questions about the milk. The milk was served into the cups right before the actual tastings. The milk samples were purchased in various grocery retail stores in the city of Kiel, Germany.

The brand names of the retail chains where the milk has been purchased are REWE, Edeka, and CITTY- 
Park (CITTI Markt der Lebensfreude). The purchased volume was around $50 \mathrm{~L}$ of milk (50 packages of $1 \mathrm{~L}$ of milk). Dates of consumer tests were as follows: University of Kiel (10 participants) on December 3, 2019; open street (food) market at Blücherplatz in Kiel (117 participants) on December 9, 12, 16, and 19, 2019; and Sheppard dog club (Kiel) on December 21, 2019 (11 participants).

After answering the general questions about milk consuming habits, the participants were conducting the paired blind preference tests with organic milk and fresh whole milk. After completion of this part of the experiment, the participants were tasting 4 studied types of milk blind (without showing a package) and then nonblind (with showing a package of the same studied 4 types of milk). To evaluate 4 offered types of milk, the participants used a 7-point Likert scale from 1 (dislike a lot) to 7 (like a lot). This way, the participants were asked to rate all investigated criteria (taste, total assessment, aroma, texture, appearance, buying decisions) for each type of milk in the questionnaire. At the end of experiment, the sociodemographic questions were presented in the questionnaire (see Appendix A: https://figshare.com/articles/journal_contribution/ Appendix_A_docx/19093532). The milk tasting and filling of the questionnaire took approximately 15 to 20 min. Between the tasting of 2 milk samples, water was offered for cleansing. As a reward and as a sign of gratitude for participating in the experiment the mandarins and some small chocolates were offered for participants after completion of the experiment. All filled paper questionnaires were collected and the data set with 138 observations was created and analyzed.

In addition, the brands of the studied milk types were selected randomly from typical supermarket product portfolios in the metropolitan area of the city of Kiel, Germany, and were kept the same for all tastings. For the walk-by interview approach, a 2-page questionnaire with 18 questions was used. These questions were divided into 5 sections: the respondent's personal milk consumption habits and milk preferences, paired onsite preference tests, blind tasting, nonblind tasting,

Table 1. Selected studies on milk tasting experiments

\begin{tabular}{|c|c|c|c|}
\hline Reference & Dairy products & Focus & Method \\
\hline Tuorila, 1987 & $\begin{array}{l}\text { Milk; } 3 \text { different fat } \\
\text { contents: nonfat }(0 \%) \text {, } \\
\text { low-fat }(1.9 \%) \text {, regular- } \\
\text { fat }(3.9 \%)\end{array}$ & $\begin{array}{l}\text { Overall liking, attitudes, norms, } \\
\text { buying intentions, reasons for shifts } \\
\text { from one milk type to another, } \\
\text { behavioral intentions }\end{array}$ & $\begin{array}{l}\text { Hedonic (sensory) tests with take-home } \\
\text { questionnaire, survey, regression model, } \\
\text { Fishbein model, 7-point scale }\end{array}$ \\
\hline $\begin{array}{l}\text { Chapman and Boor, } \\
2001\end{array}$ & Milk (3 milk types) & $\begin{array}{l}\text { Comparison of ultrapasteurized } \\
\text { (UP) and UHT milk with HTST } \\
\text { pasteurized milk, acceptance of } \\
\text { milks by children }\end{array}$ & $\begin{array}{l}\text { 7-point scale with verbal description, } \\
\text { general linear models, paired } t \text {-test, Tukey } \\
\text { paired comparison test, nonblind tasting of } \\
3 \text { milk types }\end{array}$ \\
\hline Colonna et al., 2011 & $\begin{array}{l}\text { Pasteurized and raw } \\
\text { milk specialty cheeses }\end{array}$ & $\begin{array}{l}\text { Consumers' preferences, purchasing } \\
\text { decisions, safety of raw milk cheeses, } \\
\text { packaging questions }\end{array}$ & $\begin{array}{l}\text { Blind and nonblind tastings, tasting } \\
\text { and rating of cheeses, paired preference } \\
\text { question, multinomial logit model for the } \\
\text { analysis of willingness to pay }\end{array}$ \\
\hline Weiss et al., 2015 & $\begin{array}{l}\text { Milk ( } 3 \text { types: } 2 \% \text { fat } \\
\text { milk, } 1 \% \text { fat milk, skim } \\
\text { milk) }\end{array}$ & $\begin{array}{l}\text { Consumer taste tests and milk } \\
\text { preference, willingness to purchase } \\
\text { lower-fat milk, distinguish between } \\
\text { milks of differing fat content, } \\
\text { switching to lower-fat milk after } \\
\text { taste test }\end{array}$ & $\begin{array}{l}\text { Shoppers' responses, blind taste test, } \chi^{2} \\
\text { statistics, tasting of } 3 \text { milk varieties with } 4 \\
\text { possible guesses, placing them on the game } \\
\text { board }\end{array}$ \\
\hline de Graaf et al., 2016 & Milk & $\begin{array}{l}\text { Animal welfare, price and product } \\
\text { attributes, attitudes toward dairy } \\
\text { cows, milk and milk industry }\end{array}$ & $\begin{array}{l}\text { Cross-sectional survey, online } \\
\text { questionnaire, } 5 \text {-point Likert scale, factor } \\
\text { analysis using principal components, } \\
\text { paired } t \text {-tests, linear regression model }\end{array}$ \\
\hline $\begin{array}{l}\text { Delley and Brunner, } \\
2020\end{array}$ & Milk & $\begin{array}{l}\text { Consumer behavior and needs, } \\
\text { motives and priorities for purchasing } \\
\text { milk }\end{array}$ & $\begin{array}{l}\text { Hierarchical cluster analysis, } 6 \text {-point } \\
\text { Likert scale, postal questionnaire, Ward's } \\
\text { method, the squared Euclidean distance }\end{array}$ \\
\hline
\end{tabular}


and questions about the respondent's socioeconomic situation. Other researchers developed a questionnaire with 4 sections, which contain fluid milk consumption habits; importance of product attributes for buying decisions; motives for food and fluid milk choice; sociodemographic questions (Delley and Brunner, 2020).

At the beginning of the questionnaire the question of milk consumption was presented, where the respondents had to indicate how much milk they consume per week. The answer options were no milk at all, up to $1 \mathrm{~L}, 1$ to $2 \mathrm{~L}$, and more than $2 \mathrm{~L}$. For the question about preferences for different milk types, the consumers had response options of low-fat milk, fresh whole milk, organic milk, pasture milk, long-life milk, ESL milk, certified raw milk, raw milk or milk station, and other. Multiple answers were possible. To the question of packaging size, the respondents could choose between $1 \mathrm{~L}$ and $0.5 \mathrm{~L}$.

After these questions followed the question about fat content, where the respondents could choose between response options of at least $3.5 \%, 1.5$ to $1.8 \%$, and under $0.5 \%$, which corresponds to the normal fat content levels of milk in Germany. To the question about preferred milk brands, respondents had to specify their preferred milk brands. To the question about milk usage, the consumers had to give their answers on a scale of 5 frequencies (always, often, sometimes, rarely, never), say what they preferred to use milk for (e.g., in cereal, coffee, for drinking, for hot chocolate, for cooking, for children, and for making other milk products). Similarly, respondents had to choose the importance in their buying decisions on a 5-point scale (very important, quite important, no opinion, quite unimportant, and not at all important) of each of the following characteristics: price, pasteurization, homogenization, shelf life, suitability for milk foaming, lactose-free, organic, taste, regionality, vegetarian/vegan, brand, quality, freshness, packaging size, packaging design, animal welfare, and fat content.

The second part of the questionnaire consisted of blind paired preference tests with fresh whole milk and organic milk. One pair of 2 different milk types was offered in paired preference tests, namely fresh whole milk (sample A) and organic milk (sample B). Milk sample pairs $\mathrm{C}$ and $\mathrm{D}$, and $\mathrm{E}$ and $\mathrm{F}$ were placebo samples, meaning that samples $\mathrm{C}$ and $\mathrm{D}$ were fresh whole milk, and $\mathrm{E}$ and $\mathrm{F}$ were organic milk. The purpose of this part of the experiment was to assess the reliability of stated milk taste differences. The experimental procedure for the paired preference tests was as follows:

\section{Paired blind preference tests: "Please compare the taste of each pair of milk samples" (Questionnaire Question No. 8):}

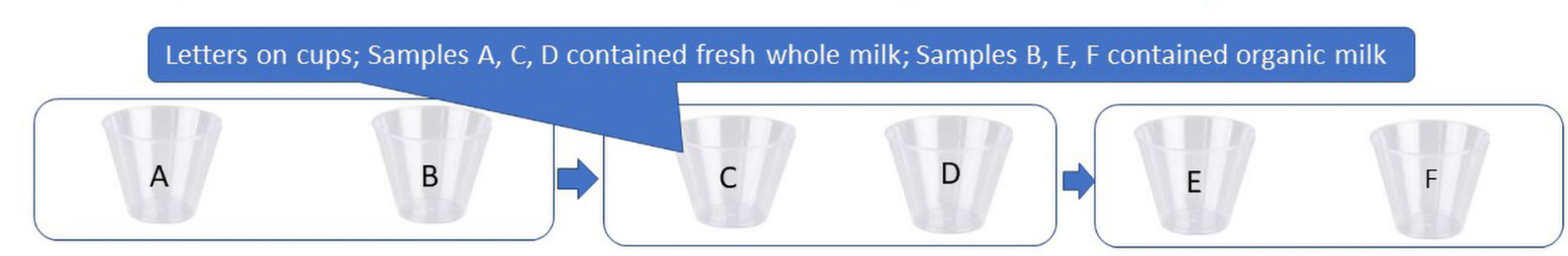

$\Rightarrow$ Instruction to respondent: "From each pair, choose the milk that you prefer"

II. Blind tests (Questionnaire Question No. 9)

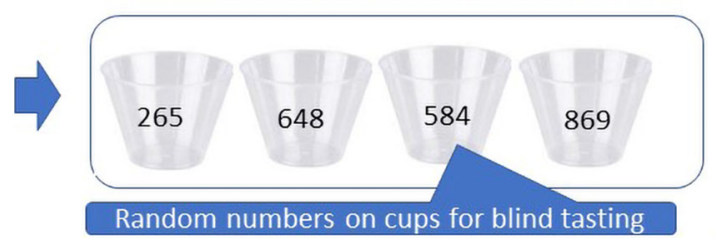

Nonblind: Cups were labelled with corresponding milk type, packages were placed next to cups

III. Nonblind tests (Questionnaire Question No. 10)

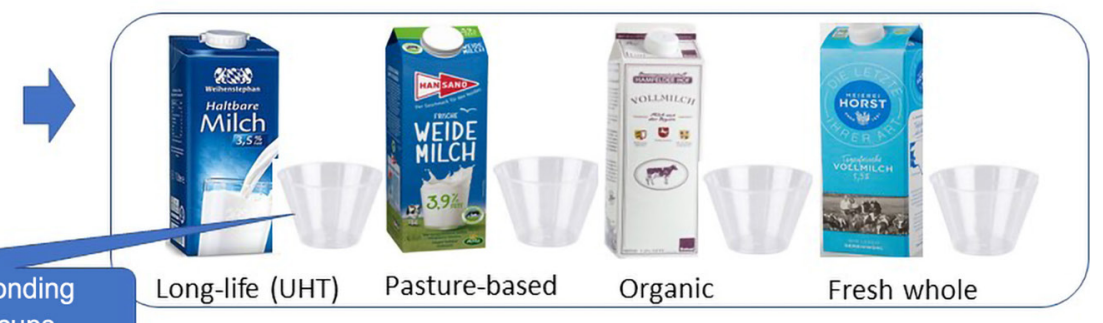

$\Rightarrow$ Instruction to respondent: "How much did you like each type milk? Evaluate each sample on the following scale:"

\begin{tabular}{|c|c|c|c|c|c|c|}
\hline 1 & 2 & 3 & 5 & 6 & 7 \\
\hline Dislike a lot & Dislike moderately & Dislike a bit & No opinion & Like a bit & Like moderately & Like a lot \\
\hline
\end{tabular}

Figure 1. Experimental setup of the present paper. Randomly selected (walk-by) participants were presented with the tasting setup shown, in the order I, II, and III, and were then asked to complete the questionnaire. 
1. The randomly selected respondent is presented with 2 blind samples $\mathrm{A}$ and $\mathrm{B}$, out of which $\mathrm{A}$ was always fresh whole milk and B was organic milk. The respondent had to indicate the preferred sample according to taste or to choose a response option of indifferent or neither.

2. The same respondent is now presented with 2 blind samples $\mathrm{C}$ and $\mathrm{D}$, out of which both were fresh cow milk. The respondent was asked to indicate the preferred choice according to taste, or "no difference," out of which the latter answer would be the expected one.

3. The same respondent is presented with 2 blind samples $\mathrm{E}$ and $\mathrm{F}$, out of which both were organic milk. The respondent was asked to indicate the preferred choice according to taste, or "no difference," out of which the latter answer would be the expected one.

The expected answers would be for the first pair either sample A or B depending on personal preferences, then indifferent between $\mathrm{C}$ and $\mathrm{D}$, and indifferent between $\mathrm{E}$ and F. Deviations from this finding give an indication about the reliability of individual taste assessments. However, we assume that these deviations are random across the sample. The response options for the first question were sample $\mathrm{A}$, sample $\mathrm{B}$, indifferent, and neither; for the second question, instead of sample $\mathrm{A}$ and $\mathrm{B}$, were sample $\mathrm{C}$ and $\mathrm{D}$ with indifferent and neither; in the third question the consumers had to choose between response options of sample E and F, indifferent, and neither.

The respondents were given 2 pairs of placebo samples and had to choose between the 2 or give the option indifferent or neither. The placebo pairs of milk were tested after the target milk samples (Zhang et al., 2016), but the respondents were given the placebo pair they preferred in the first test (Zhang et al., 2016). For the tasting, 2 placebo pairs with organic milk and fresh whole milk were presented to all the respondents to identify whether they could distinguish between organic milk and conventional fresh whole milk by taste. All the milk samples were tasted blind in transparent glasses, marked with the letters A, B, C, D, E, and F so that the respondents were unaware which milk they were tasting or that the placebo pair existed. However, using letters is common when conducting paired preference tests. Various studies of milk and dairy products that used paired preference tests in different contexts have applied similar abbreviations for the samples, such as sample A and sample B for samples of strawberry yogurts (Villegas-Ruiz et al., 2008). Paired preference tests were conducted by Halim et al. (2020) using coded alternatives as A, B, and no preference.
The third part of the questionnaire was blind milk tasting with respondents without them knowing the milk brand and included questions on taste, smell, texture, appearance, and overall assessment of 4 different milk types (long-life milk, pasture milk, organic milk, and fresh whole milk) on a 7 -point scale from 1 (dislike a lot) to 7 (like a lot). After evaluating the milk samples, the respondents had to rank the different milk types (from first to fourth place), placing the best milk type in the first position and other milk types further down the ranking according to their preferences. The respondents had to choose whether they would be willing to buy each specific type of milk or not and explain their buying decision for milk. The fourth part of the questionnaire was a nonblind tasting experiment where the milk brand (packaging) was visible to the respondents. The questions in the fourth part were identical to those in the third part. The final section of the questionnaire included questions about the respondents' age, gender, household size, number of children, education level, and income. Each respondent completed this part at the end of the tasting experiment.

The experiments were conducted with people in 3 different locations: shoppers in the open street market on Blücherplatz in Kiel (Schleswig-Holstein, Germany) during the market's opening hours (0800-1300 h), students at Christian-Albrechts-University of Kiel, and members of the Shepherd dog club in Kiel (Shepherd dog clubs tend to attract people from all parts of society). The data from the 3 locations were collected from December 9 to 19, 2019, on December 3, 2019, and on December 21, 2019. The milk samples were served in $50-\mathrm{mL}$ transparent plastic glasses coded by randomly selected 3-digit numbers during the blind tasting (Tuorila, 1987; Colonna et al., 2011; Weiss et al., 2015).

Between sample tastings, water (Tuorila, 1987; Bakke et al., 2016) and crackers (Young et al., 2004; Villalobos-Chaparro et al., 2018) were offered to cleanse the respondents' palate. The paper questionnaires were completed by the respondents while they did the tastings.

\section{RESULTS}

\section{Statistical Analysis}

Collected data were entered into a data set in IBM SPSS Statistics Version 23 (IBM). Statistical analysis of entered data was performed in IBM SPSS Statistics Version 23 and Stata/SE 15.1 for Windows (paired $t$-tests and multilevel mixed-effects logistic regression models, respectively). Paired $t$-tests for comparison of differences in taste evaluations between pairs of types of milk under blind and nonblind tastings were con- 
ducted using the threshold of $P<0.05$ for statistical significance.

Multilevel mixed-effects logistic regression models were performed using the threshold of $P<0.1$ for statistical significance. The dependent variable in the multilevel mixed-effects logistic regression models was obtained from the question "Buying decision: Yes/no." To assess respondents' preferences, the hypothesis was that various socioeconomic characteristics influence the likelihood of buying a certain type of milk. To test this, the following random intercept model specification was estimated using the melogit command in Stata/SE 15.1 for Windows, with a random effect specified at the level of each respondent $j$ over $i$ tastings (Equation 1):

$$
y_{i j}=\beta_{0}+\beta_{j} X_{i j}+\mu_{0 j}+u_{i j}
$$

where $X$ represents the explanatory variables of gender, age in years, household size, income, education, number of children, total assessment of the milk, and taste. The estimated coefficient $\beta$ represent sample-generic coefficients. The parameter $\mu_{0 j}$ is an individual-specific random effect and $u_{i j}$ is the term of regression residuals that is assumed to be $N\left(0, \sigma^{2}\right)$. The random effects specification allows individual heterogeneity to be captured in preferences more effectively than a conventional logit approach.

The null hypothesis implied by each coefficient states that there is no statistically significant relationship between respondents' stated buying intentions and any of the explanatory variables. The alternative hypothesis implies that respondents' indicated buying decisions are influenced by taste, overall assessment, gender, age, household size, number of children, level of education, and income.

\section{Descriptive Results}

Socioeconomic Sample Characteristics. Table 2 presents the socioeconomic sample characteristics compared with the average German population for 2019. In other words, Table 2 demonstrates the representa-

Table 2. Comparison of sample characteristics with the average German population for 2019

\begin{tabular}{lll}
\hline Index & $\begin{array}{l}\text { Sample } \\
\text { characteristics, } \%\end{array}$ & $\begin{array}{l}\text { Average German } \\
\text { population, \% }\end{array}$ \\
\hline Age (yr) & Under 18: 3.8 & Under 19: 18.4 \\
& 18-35: 30.3 & $20-39: 24.6$ \\
& $36-60: 43.2$ & $40-59: 28.8$ \\
Ratio male/female & 0.90 & Over 60: 28.2 \\
\hline
\end{tabular}

tiveness of the sample through a comparison with the German population in 2019. In addition, Table 2 shows that the sample characteristics almost fully reflected the average German population characteristics, thus it can be concluded that the sample was representative of the corresponding characteristics of the German population.

Sample Characteristics of Fresh Milk Consumption. The majority of the participants $(52.2 \%)$ preferred to consume up to $1 \mathrm{~L}$ of milk/wk, $22.1 \%$ consumed between 1 and $2 \mathrm{~L}$ of milk/wk, $21.3 \%$ consumed more than $2 \mathrm{~L}$ of milk/wk, and $4.4 \%$ did not consume milk at all. Women in the sample tended to consume less milk: the majority of women $(60.9 \%)$ consumed less than $1 \mathrm{~L}$ of milk/wk, and the majority of men $(43.5 \%)$ also consumed less than $1 \mathrm{~L}$ of milk/wk. At the same time, $32.3 \%$ of male respondents and just $13.0 \%$ of females consumed more than $2 \mathrm{~L}$ of milk/wk. Around $60 \%$ of respondents who did not consume milk at all were women, and $40 \%$ were men.

The majority of the respondents $(60 \%)$ who did not consume milk at all were over 60 , whereas around $40 \%$ of the respondents who consumed up to $1 \mathrm{~L}$ of milk/wk were aged between 36 and 60 (Figure 2). In addition to this, the majority of respondents $(36 \%)$ who consumed between 1 and $2 \mathrm{~L}$ of milk/wk were of a similar age. Around $60 \%$ of the respondents who consumed more than $2 \mathrm{~L}$ of milk/wk were also in this age group (36-60). Therefore, it can be concluded from the present study results that dairy companies should focus their advertising campaigns at people between 36 and 60 years because the respondents in this group consumed more milk per week.

Around $31 \%$ of the respondents aged 36 to 60 consumed more than $2 \mathrm{~L}$ of milk/wk, whereas around $28 \%$ of the respondents aged between 18 and 35 consume the same amount of milk, as well as around $3 \%$ of respondents aged over 60 years and no respondents under 18 at all.

Most respondents from all income groups consumed up to $1 \mathrm{~L}$ of milk/wk, whereas the majority of respondents (50\%) who consumed no milk at all had an income of $€ 1,000$ to $€ 2,000 / \mathrm{mo}(€ 1=\mathrm{US} \$ 1.11$ at the time of the study). However, up to $1 \mathrm{~L}$ of milk/wk was consumed by around $50 \%$ of respondents with an income above $€ 2,000 / \mathrm{mo}, 52 \%$ of respondents with an income of $€ 1,000$ to $€ 2,000 / \mathrm{mo}$, and around $61 \%$ of respondents with an income below €1,000/mo. Around $46 \%$ of the respondents who consumed between 1 and 2 $\mathrm{L}$ of milk/wk had an income of more than $€ 2,000 / \mathrm{mo}$, and the majority of the respondents (around 46\%) who consumed more than $2 \mathrm{~L}$ of milk/wk had the same high income. Therefore, it would appear that people with 


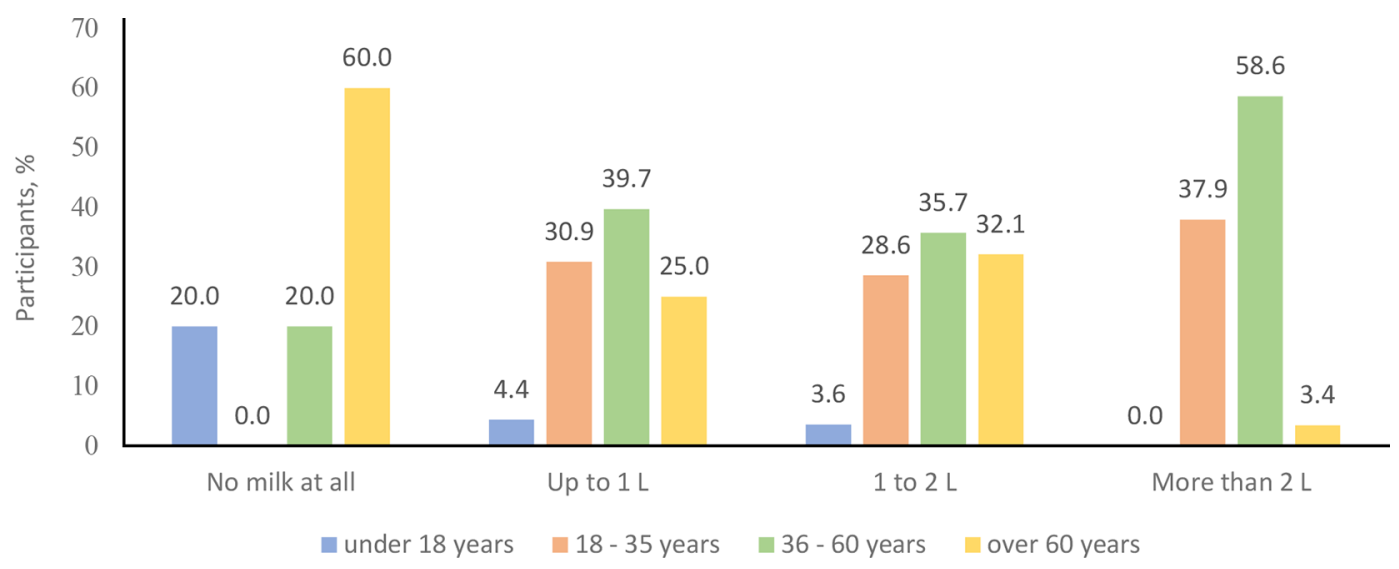

Figure 2. Milk consumption per week according to the age of the respondents.

higher incomes consume slightly more milk than people with lower incomes.

Regarding the packaging volume, $91 \%$ of all participants of the study preferred 1-L milk packaging, whereas $9.0 \%$ of participants preferred 0.5 -L milk packaging. However, women tended to prefer smaller packaging than men, with $75 \%$ of those who preferred 0.5 -L milk packaging being women. Regarding fat content, $82.7 \%$ of respondents preferred at least $3.5 \%$ fat in their milk, and $17.3 \%$ of respondents preferred milk with a fat content of between 1.5 and $1.8 \%$.

The majority of consumers reported that they buy mostly organic milk (61.7\%), followed by fresh whole milk (28.6\%), and pasture milk $(24.8 \%)$. In other words, organic milk was the most popular type of milk (Figure 3 ), even though this result from the survey contrasts with the actual size of the German milk market segments, where organic milk only accounts for a small proportion. In the German dairy market, the share of organic milk in the country was $2.6 \%$ at 0.83 billion L of organic milk production in 2017. With a share of global total organic milk production of $11.6 \%$, Germany ranks third in the production volume of organic milk worldwide and organic milk production grew by $4.9 \%$ in the period from 2012 to 2017 (GOMPMR, 2018).

Regarding the question "Which milk brands do you prefer?" the majority of consumers $(60.2 \%)$ chose Hamfelder Hof" followed by Ja (11.8\%), and Hansano (8.6\%). The brands Nestle, Hemme Milch, Arla, Milsani, Welde, Demeter, Öko Melkburen, and Bärenmarke each were chosen by $1.1 \%$ of consumers. Therefore, the majority of respondents preferred organic milk and the Hamfelder Hof brand (Figure 4). However, as this question was formulated as an open question, the respondents could point out their preferred milk brands without predefined options.

The majority of respondents used milk for coffee (63.63\%), 53.98\% used milk with cereal, $35.18 \%$ used milk directly for drinking, $33.33 \%$ used milk for cooking, $30.69 \%$ stated they buy milk for their children's nutrition, $27.68 \%$ used it for hot chocolate, and $12 \%$ used it to make other milk-based products (Figure 5).

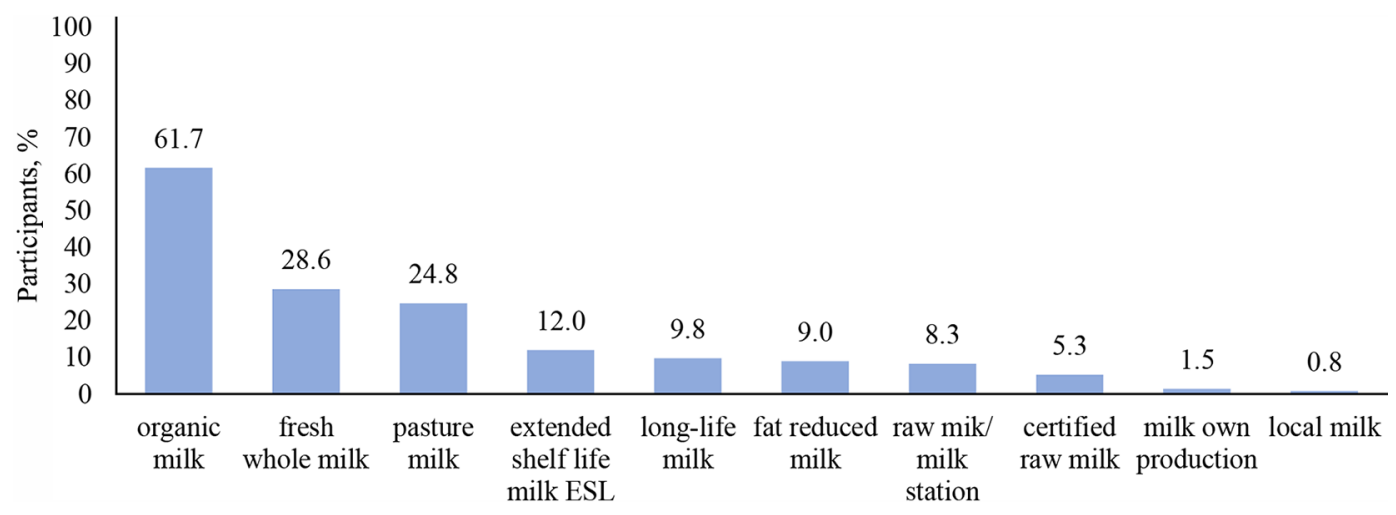

Figure 3. Responses of milk tasting experiment participants to the question, "Which type of milk do you buy most?" (multiple response question). 


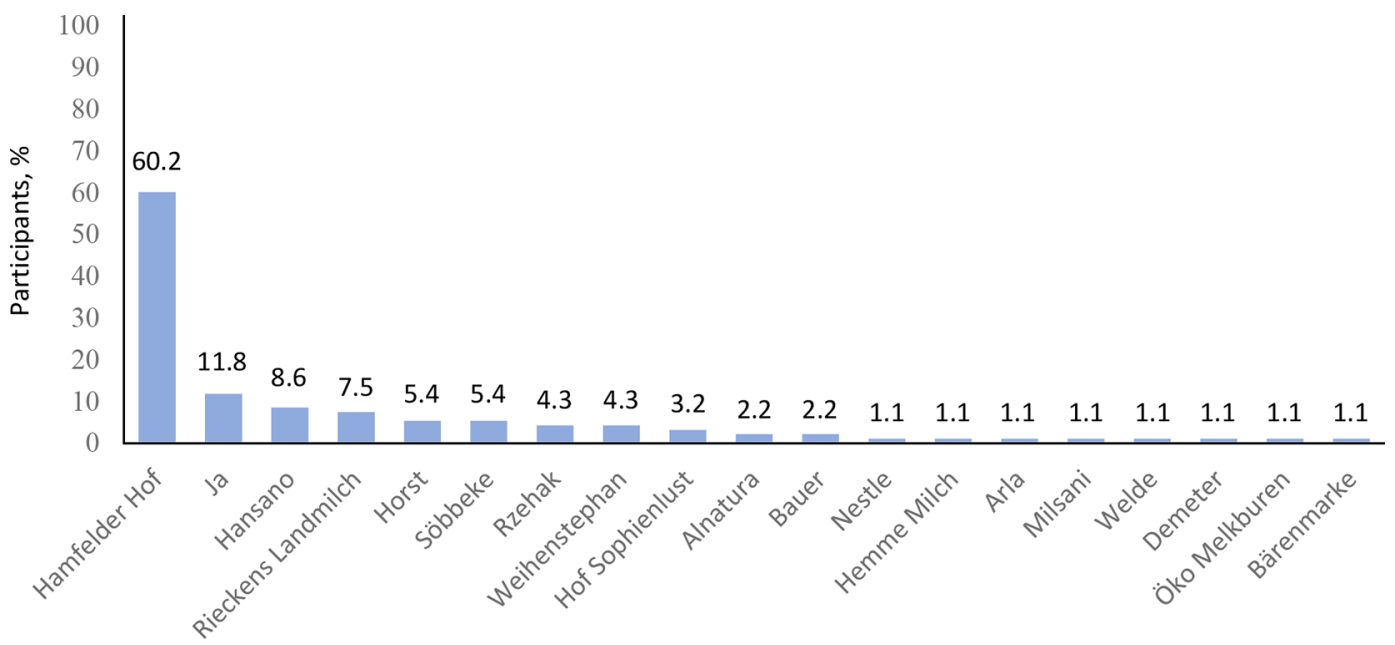

Figure 4. Participants' responses to the question "Which milk brands do you prefer?" (multiple response question).

The following criteria were very important and quite important for the respondents for buying decisions for milk: freshness (93.6\%), quality (93.33\%), taste $(89.76 \%)$, animal welfare $(89.31 \%)$, and regionality $(87 \%)$. In addition, only $8.1 \%$ of respondents evaluated the criterion price as very important for buying decision for milk. Around $15 \%$ of participants found the criterion packaging design very important and quite important, whereas just $5 \%$ of participants reported that the criterion lactose-free is very important and quite important for their buying decisions for milk.

\section{Results from Paired t-Tests}

In blind paired preference tests, $23.31 \%$ of participants were able to correctly identify the same taste of both placebo samples and answered "indifferent" for fresh whole milk, and $27.91 \%$ of participants were able to identify that organic milk was offered twice. During paired blind preference tests between fresh whole milk and organic milk (samples A and B), around $41 \%$ of respondents preferred sample A (fresh whole milk), and around $48 \%$ of respondents preferred sample B (organic milk), whereas approximately $11 \%$ of participants chose the response option "indifferent."

The taste of long-life milk pairs under blind tasting and long-life milk under nonblind tasting (Table 3) was statistically significantly different. The variable taste had a 7 -point scale from the minimum 1 (dislike a lot) to a maximum 7 (like a lot). Under blind and nonblind tastings, the tastes of long-life milk, pasture-based milk, organic milk, and fresh whole milk were evaluated significantly different.

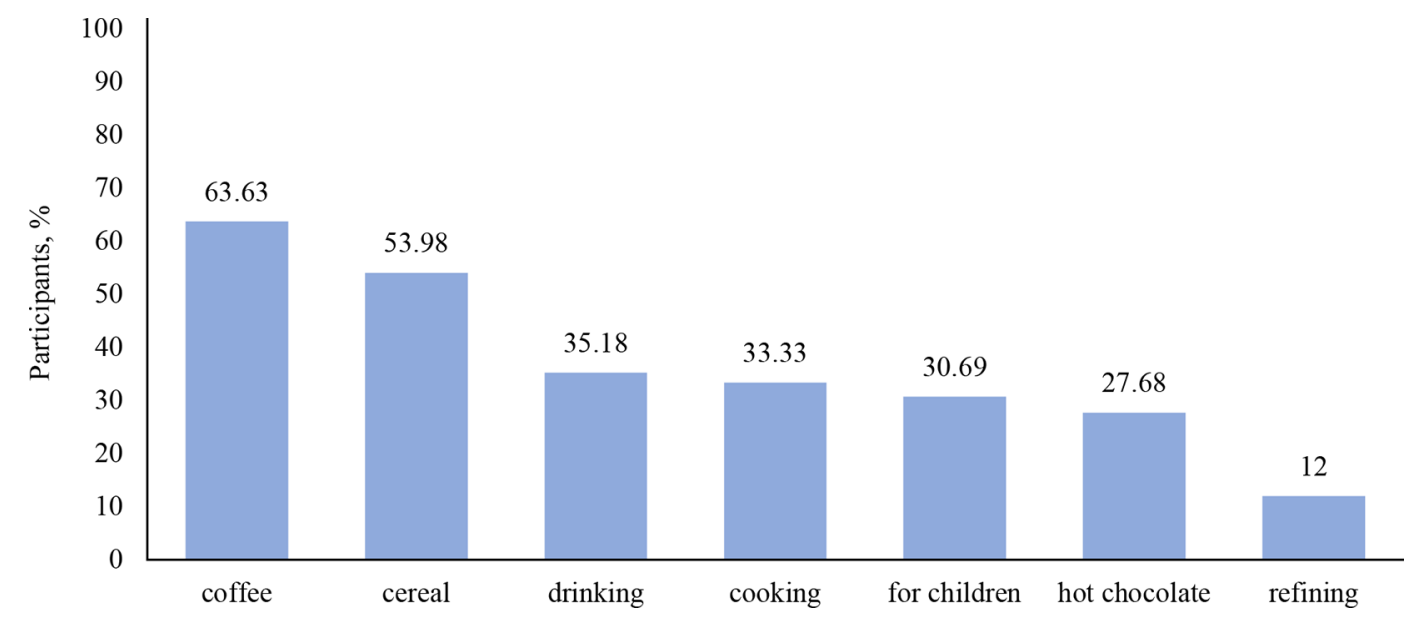

Figure 5. Milk tasting experiment participants' ways of using milk (frequently and very frequently), as stated in the participants' responses to the question, "How do you use milk?" (multiple response question). 
Table 3. Comparison of paired $t$-tests for means of taste evaluations for blind and nonblind tasted milk types

\begin{tabular}{|c|c|c|c|}
\hline Pair & Taste test & Mean $^{1}$ & $\begin{array}{c}\text { Significance }(2 \text {-tailed }), \\
P \text {-value }\end{array}$ \\
\hline \multirow[t]{2}{*}{1} & Long-life milk (blind) & 3.60 & 0.000 \\
\hline & Long-life milk (nonblind) & 2.95 & \\
\hline \multirow[t]{2}{*}{2} & Pasture milk (blind) & 3.95 & 0.047 \\
\hline & Pasture milk (nonblind) & 4.26 & \\
\hline \multirow[t]{2}{*}{3} & Organic milk (blind) & 4.51 & 0.000 \\
\hline & Organic milk (nonblind) & 5.21 & \\
\hline \multirow[t]{2}{*}{4} & Fresh whole milk (blind) & 4.06 & 0.002 \\
\hline & Fresh whole milk (nonblind) & 4.56 & \\
\hline
\end{tabular}

The present study results indicated that the respondents were influenced by the image and packaging of different milk types, and evaluated the taste of milk differently depending on whether they were tasting blind or nonblind. By comparing the taste perception of different milk types in the blind tastings (Table 4), the long-life milk was evaluated statistically significantly differently from organic milk (both under blind

Table 4. Comparison of the taste of different milk types with paired $t$-tests under blind and under nonblind tasting

\begin{tabular}{|c|c|c|}
\hline Paired comparison & Mean $^{1}$ & $\begin{array}{c}\text { Significance }(2 \text {-tailed }) \\
P \text {-value }\end{array}$ \\
\hline \multicolumn{3}{|l|}{ Blind tasting } \\
\hline Long-life milk & 3.6 & 0.114 \\
\hline Pasture milk & 3.95 & \\
\hline Long-life milk & 3.6 & 0.000 \\
\hline Organic milk & 4.51 & \\
\hline Long-life milk & 3.6 & 0.042 \\
\hline Fresh whole milk & 4.06 & \\
\hline Pasture milk & 3.95 & 0.003 \\
\hline Organic milk & 4.51 & \\
\hline Pasture milk & 3.95 & 0.526 \\
\hline Fresh whole milk & 4.06 & \\
\hline Organic milk & 4.51 & 0.015 \\
\hline Fresh whole milk & 4.06 & \\
\hline \multicolumn{3}{|l|}{ Nonblind tasting } \\
\hline Pasture milk & 4.26 & 0.000 \\
\hline Long-life milk & 2.95 & \\
\hline Pasture milk & 4.26 & 0.000 \\
\hline Organic milk & 5.21 & \\
\hline Pasture milk & 4.26 & 0.043 \\
\hline Fresh whole milk & 4.56 & \\
\hline Long-life milk & 2.95 & 0.000 \\
\hline Organic milk & 5.21 & \\
\hline Long-life milk & 2.95 & 0.000 \\
\hline Fresh whole milk & 4.56 & \\
\hline Organic milk & 5.21 & 0.000 \\
\hline Fresh whole milk & 4.56 & \\
\hline
\end{tabular}

\footnotetext{
${ }^{1}$ The scale for calculating the means for taste evaluations for each type of milk was from 1 (dislike a lot) to 7 (like a lot).

${ }^{2}$ The threshold for significance was defined as $P<0.05$.
}

tasting), and the taste of long-life milk was evaluated statistically significantly differently from fresh whole milk under blind tasting.

Significant differences in the evaluations of taste were also found when comparing the blind tasting of pasture-based milk with organic milk, and comparing organic milk with fresh whole milk under blind tasting. No significant difference was found between the blind tasting of long-life milk and pasture milk, as well as between the blind tasting of pasture milk and fresh whole milk. This finding means that participants evaluated these milk types similarly and were unable to identify any difference in the taste of these milk types. The present study results showed that the taste of almost all milk types was statistically significantly different from each other even under blind tasting.

The comparison of taste perceptions from nonblind tastings (Table 4) of pasture milk and long-life milk was significantly different, as well as by pairs of pasture milk and organic milk, pasture milk and fresh whole milk, long-life milk and organic milk, long-life milk and fresh whole milk, and organic milk and fresh whole milk. Apparently because of the influence of packaging and the image of credence-good-related attributes under nonblind tasting, all milk types were evaluated significantly different from each other.

The majority of participants $(78.7 \%)$ liked the taste of organic milk more than the other types of milk under nonblind tasting, whereas this was the case for just $59.5 \%$ of the respondents under blind tasting. For long-life (UHT) milk, the evaluation was the opposite: more consumers liked the taste of long-life milk under blind tasting (36.4\%) than under nonblind tasting $(19.9 \%)$. In other words, brand effects may play an essential role in consumer preferences regarding different milk types because the same milk types (organic milk and long-life milk) were evaluated very differently under blind and nonblind tastings (Figure 6; Figure 7; Figure 8). In other studies, researchers demonstrated 


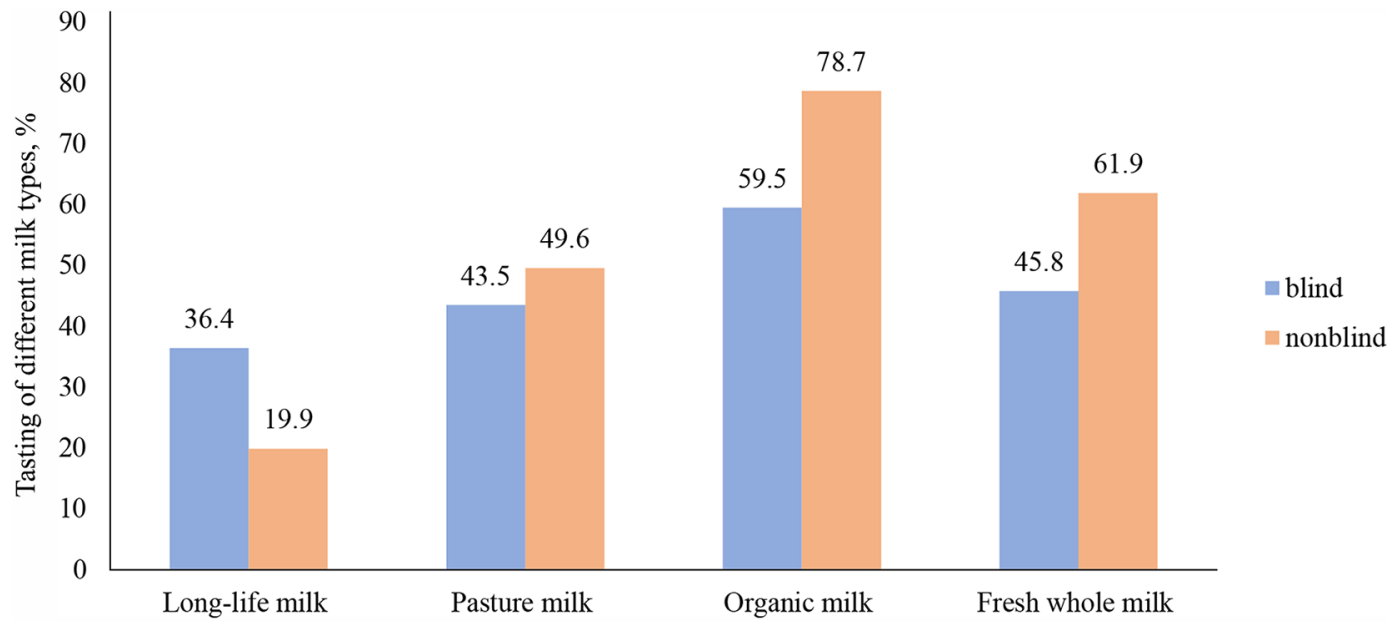

Figure 6. Blind versus nonblind tasting for the taste for different milk types (sum of "like a lot deal," "like a moderate amount," and "like a little").

that conventional milk was perceived more negatively than organic, local, and pasture-based milk, whereas blinded preference tests revealed that preferences are determined mostly through flavor and in nonblinded tests consumers evaluated milk types based on their explicit beliefs (Harwood and Drake, 2020).

However, the only exception was in the evaluation of the taste of pasture milk, which turned out to be not very different between the blind and nonblind tastings: $43.5 \%$ of the respondents liked the taste of pasture milk under blind tasting, and $49.6 \%$ liked the taste of pasture milk under nonblind tasting. The fresh whole milk seemed to have a better image than long-life and pasture milk, because $61.6 \%$ of respondents liked fresh

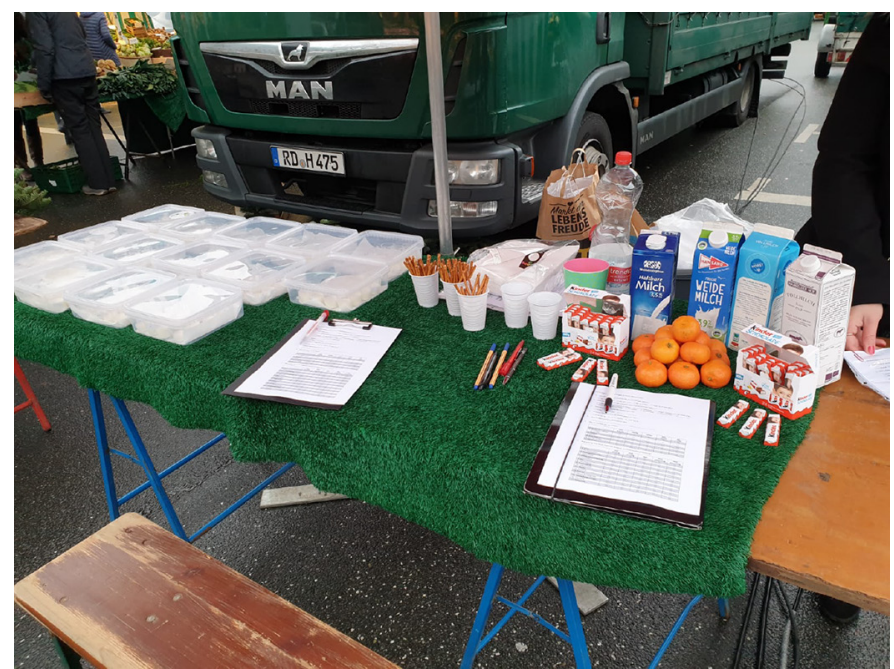

Figure 7 . The tasting table from the milk tasting experiment. whole milk under nonblind tasting, whereas $45.8 \%$ of respondents liked the taste of this type of milk under blind tasting.

\section{Multilevel Mixed-Effects Logistic Regression Models}

To identify which factors influenced the respondents' stated buying decision (intention) for the studied 4 types of milk, multilevel mixed-effects logistic regression models were used (Table 5, Table 6). As can be seen from Table 5 , the buying decision for long-life milk under blind tasting depended on the overall assessment and income. The higher the overall assessment of this type of milk, the greater the probability of buying long-

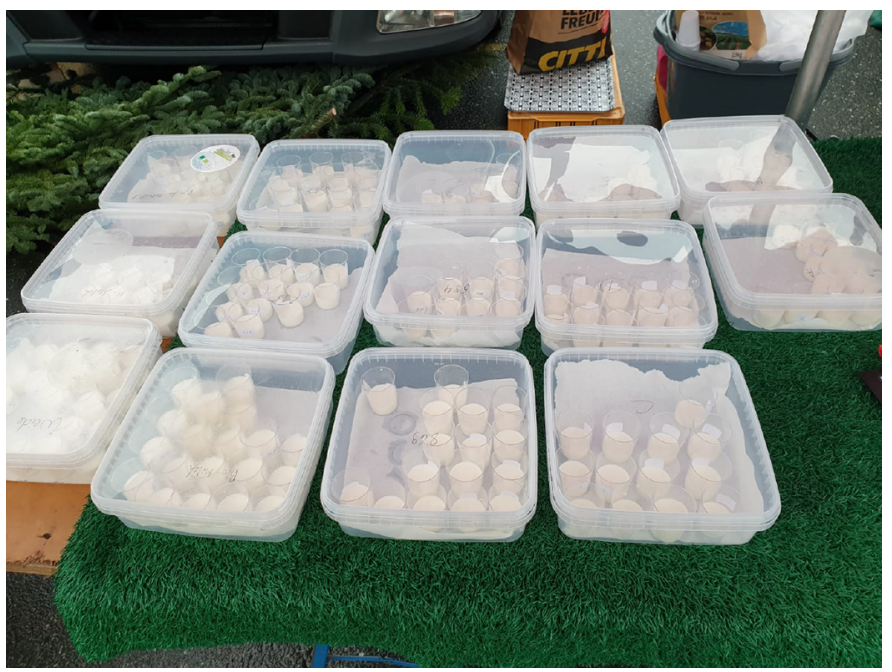

Figure 8. The milk samples from the milk tasting experiment. 
Table 5. Multilevel mixed-effects logistic regression models with dependent variables buying decisions for long-life and pasture milk under blind and nonblind tasting

\begin{tabular}{|c|c|c|c|c|c|c|c|c|}
\hline \multirow[b]{2}{*}{ Variable } & \multicolumn{2}{|c|}{$\begin{array}{l}\text { Buying decision } \\
\text { long-life milk blind }\end{array}$} & \multicolumn{2}{|c|}{$\begin{array}{l}\text { Buying decision long-life } \\
\text { milk nonblind }\end{array}$} & \multicolumn{2}{|c|}{$\begin{array}{l}\text { Buying decision } \\
\text { pasture milk blind }\end{array}$} & \multicolumn{2}{|c|}{$\begin{array}{l}\text { Buying decision pasture } \\
\text { milk nonblind }\end{array}$} \\
\hline & Coefficient & $P>|z|^{1}$ & Coefficient & $P>|z|$ & Coefficient & $P>|z|$ & Coefficient & $P>|\mathrm{z}|$ \\
\hline Taste & 0.3314 & 0.1812 & 1.6709 & 0.0556 & 0.4070 & 0.0291 & 0.7239 & 0.0030 \\
\hline Total_assessment & 0.9791 & 0.0160 & -0.3525 & 0.5768 & 1.3726 & 0.0024 & 0.5807 & 0.0558 \\
\hline Gender ( $=1$ if male $)$ & -0.1518 & 0.7460 & 0.5870 & 0.5977 & 0.4764 & 0.3683 & 0.4778 & 0.3044 \\
\hline Age in years & 0.5275 & 0.1105 & -0.6643 & 0.1763 & 0.0295 & 0.9292 & 0.3817 & 0.2418 \\
\hline Level of education & 0.2017 & 0.3878 & 0.2021 & 0.5549 & 0.1084 & 0.6713 & 0.1071 & 0.5112 \\
\hline Income & -0.8721 & 0.0236 & -0.9197 & 0.0891 & 0.4751 & 0.2197 & -0.7948 & 0.0180 \\
\hline Cons & -8.9711 & 0.0002 & -7.4781 & 0.0867 & -12.935 & 0.0000 & -7.9335 & 0.0000 \\
\hline
\end{tabular}

${ }^{1}$ The threshold for significance was defined as $P<0.1 . P>|z|$ means $P$-value for testing the null hypothesis, which assumes that the coefficient of each variable is zero, based on z-statistics.

life milk under blind tasting. A higher consumer income reduced the probability of buying long-life milk under blind tasting, which showed long-life milk's inferior image. The better evaluation given to the taste of long-life milk in nonblind tasting, the more likely the respondent was to purchase this type of milk. With rising income, the probability of buying long-life milk decreased.

The higher the ratings for taste and overall assessment of pasture milk under blind tasting, the greater the probability of this type of milk being purchased. Under the nonblind tasting of pasture milk, according to the magnitude of the estimated coefficients, better taste evaluations led to no substantial increase in the probability of this type of milk being bought relative to the blind experiment. A higher rating for overall assessment led to a greater probability of pasture milk being bought under nonblind tasting. In addition, the higher the income, the less likely people were willing to buy pasture milk. In other words, pasture milk had no significant positive image effect.

Table 6 shows that the higher the rating for the taste and overall assessment of organic milk under blind tasting, the greater the probability of organic milk being purchased. For female consumers, the probability of buying organic milk was higher than for male consumers, which was found in both the blind and nonblind tasting. Under nonblind tasting, better taste evaluations also led to a greater probability of a willingness to buy organic milk. The results of other studies revealed that the organic attribute was ranked as the eighthmost important out of 14 studied attributes for purchasing of milk. The first position was given to the fat content, followed by flavor, package size, and price (Harwood and Drake, 2018). However, it was also found out that health, availability, and education influence buying decisions of organic milk (Paul and Rana, 2012), whereas

Table 6. Multilevel mixed-effects logistic regression models with dependent variables buying decisions for organic milk and fresh whole milk under blind and nonblind tasting

\begin{tabular}{|c|c|c|c|c|c|c|c|c|}
\hline \multirow[b]{2}{*}{ Variable } & \multicolumn{2}{|c|}{$\begin{array}{l}\text { Buying decision } \\
\text { organic milk blind }\end{array}$} & \multicolumn{2}{|c|}{$\begin{array}{l}\text { Buying decision } \\
\text { organic milk nonblind }\end{array}$} & \multicolumn{2}{|c|}{$\begin{array}{l}\text { Buying decision fresh } \\
\text { whole milk blind }\end{array}$} & \multicolumn{2}{|c|}{$\begin{array}{l}\text { Buying decision fresh } \\
\text { whole milk nonblind }\end{array}$} \\
\hline & Coefficient & $P>|\mathrm{z}|^{1}$ & Coefficient & $P>|z|$ & Coefficient & $P>|z|$ & Coefficient & $P>|\mathrm{z}|$ \\
\hline Total_assessment & 1.4145 & 0.0590 & 0.0503 & 0.8631 & 1.1804 & 0.0018 & 0.7301 & 0.0101 \\
\hline Gender ( = 1 if male) & -1.5103 & 0.1158 & -0.9651 & 0.1019 & 0.2214 & 0.6369 & -0.0238 & 0.9596 \\
\hline Age in years & -0.1445 & 0.8003 & -0.3749 & 0.4203 & 0.0953 & 0.7340 & -0.5011 & 0.1671 \\
\hline Level of education & -0.5270 & 0.2208 & 0.1819 & 0.3989 & 0.0560 & 0.7154 & -0.3522 & 0.1105 \\
\hline Income & 0.0779 & 0.8924 & -0.1180 & 0.7988 & 0.5537 & 0.1000 & 0.6921 & 0.0393 \\
\hline Cons & -11.2386 & 0.0148 & -3.2393 & 0.1040 & -11.656 & 0.0000 & -5.1392 & 0.0151 \\
\hline
\end{tabular}

${ }^{1}$ The threshold for statistical significance was defined as $P<0.1 . P>|\mathrm{z}|$ means $P$-value for testing the null hypothesis, which assumes that the coefficient of each variable is zero, based on z-statistics. 
age can play an important role for the buying decision of organic milk as well (Harwood and Drake, 2018).

Higher scores for the taste and total assessment evaluations of fresh whole milk led to a greater willingness to buy this type of milk under blind tasting. A higher income increased the probability of buying fresh whole milk under blind tasting. A better taste evaluation, higher total assessment and higher income led to a greater probability of fresh whole milk being bought under nonblind tasting.

Finally, under blind and nonblind tasting of almost all milk types, the taste, total assessment of the milk, and income played the most important roles in the consumers' buying decisions. Other researchers indicated that such factors as income, education, and lifestyle habits can influence purchasing decisions of milk, whereas for consumers of organic milk and dairy products, such factors as enhanced nutrition, environmental sustainability, ethical animal treatment, or local farm support affect purchasing decisions (Harwood and Drake, 2018).

\section{DISCUSSION}

The aim of this study was to analyze if and to what extent a sample of randomly selected consumers could distinguish between 4 types of milk-UHT long-life milk, conventional pasteurized drinking milk, pasturebased conventional milk, and organic milk-on the basis of taste and overall assessment, and whether the presence of the relevant milk packaging altered their preference assessments.

The study also investigated how milk brand or credence-good-related image influenced consumer preferences and their willingness to buy milk (buying decision), as well as how and if the different milk types differed in taste. The question was whether by tasting milk without the presence of packaging (blind), the respondents would give similar evaluations to the milk properties as when tasting the milk with the packaging present. In the case of the same results of both milk tastings, the brand or the credence image has no significant influence on consumers' perception of the milk, consumers' preferences are influenced by the brand or credence image.

According to the results of present study, around $52 \%$ of consumers preferred to consume up to $1 \mathrm{~L}$ of milk/wk, whereas the study of de Graaf et al. (2016) showed that the majority of participants (around 54\%) consumed milk at least once per day. According to the results of the present study, the respondents mostly used milk for coffee, and the important criteria in milk buying decisions were freshness, quality, and taste, whereas the study of de Graaf et al. (2016) confirmed the results of the present study that the most important milk attributes were freshness and safety. The top criterion in the buying decision was freshness, which was chosen by $93.6 \%$ of consumers, with the criterion organic preferred by $81.4 \%$ of respondents. The participated consumers preferred organic milk (78.7\%) and fresh milk (61.9\%) to long-life milk (19.9\%) under nonblind tasting (Figure 6), what can show the better image of these types of milk comparing to long-life milk. Interestingly, under the blind and nonblind tasting of organic milk, the factor of gender played a significant role in the buying decision, with women being more likely to buy organic milk than men.

The taste of long-life milk was evaluated much better blind than nonblind, and the taste of organic milk was evaluated much better nonblind than blind. For pasture milk and fresh whole milk, the evaluations of taste under nonblind tasting were slightly more positive than under blind tasting.

It can be concluded that consumers were influenced by the packaging or image of the milk. The very positive image of organic milk and very negative image of long-life (UHT) milk can play a role for buying decisions and preference of specific milk type.

A higher income is related to a smaller probability of buying long-life milk under the blind and nonblind tasting, and pasture milk under nonblind tasting. However, a higher income leads to a greater probability of buying fresh whole milk under blind and nonblind tasting. Therefore, there is a negative income effect for long-life milk and pasture milk, and a positive effect for fresh whole milk. Furthermore, the higher the rating respondents gave to both the total assessment and taste of milk types, the more likely they were willing to buy the studied types of milk.

Respondents who consume more than $1 \mathrm{~L}$ of milk/wk tended to prefer less fat in their milk, and older respondents tend to prefer a higher fat content in their milk (Andersen and Smed, 2013). However, in the present study almost $90 \%$ of the respondents who consumed between 1 and $2 \mathrm{~L}$ of milk/wk tended to prefer at least $3.5 \%$ of fat in their milk.

Furthermore, consumers with a basic education and low income usually pay attention to the price of milk (Celik Ates and Ceylan, 2010). This finding was confirmed in the present study. The majority of respondents who defined price as a very important criterion in their milk buying decision had an income of less than $€ 1,000 / \mathrm{mo}$.

In the paired $t$-tests, brand was found to influence the milk evaluations because consumers rate branded milk more favorably than unbranded milk (Joubert and Poalses, 2012). This finding was also confirmed by the 
results of the present study (except for the evaluations of long-life milk). Considering the living locations, it was found that, suburban consumers prefer organic milk and lower-fat conventional milk (Chang et al., 2011), whereas the results of the present study showed that around $62 \%$ of respondents preferred organic milk to other types of milk. In addition, the vast majority of respondents preferred at least a $3.5 \%$ fat content in milk.

According to Dimitri and Venezia (2007), a higher income and higher level of education suggest a preference for organic milk. However, the results of the present study suggested that income and education level did not significantly affect the probability of purchasing organic milk, and organic would appear to be a very important criterion in the buying decision of middle-aged female respondents (36-60 yr), especially if they had an income above $€ 2,000 / \mathrm{mo}$ and a university degree.

According to Chang et al. (2011), the most important factors determining the consumption of whole milk are taste and preferences, whereas in the present study the buying decisions of almost all studied milk types were affected by taste, as well as by the overall assessment of each specific milk type. Other researchers have found that the consumer preferences for milk were influenced mostly by taste and texture of the milk (Colonna et al., 2011). The findings of the present study suggested that almost $64 \%$ of all respondents identified taste as a very important criterion in their buying decision, with the majority aged between 36 and 60 . However, other studies (e.g., Kurajdová et al., 2015) have found that the criterion taste is more important for younger people, whereas for older people it is the healthiness of milk that plays the greatest role. Papafotikas et al. (2014) found that price and quality primarily affect consumers' purchasing decisions. The results of the present study also suggested the great importance of criterion quality as a determinant of the buying decision because it was selected by $68 \%$ of respondents.

The flavor, sweetness, aroma, and mouthfeel of milk are given a poorer evaluation blind than nonblind when respondents are given information about animal welfare (Jiang et al., 2021), whereas in the present study the blind evaluations of milk taste were worse for organic milk, pasture milk, and fresh whole milk than the nonblind evaluations. Only long-life milk received a better evaluation under the blind testing than in the nonblind tasting. Furthermore, the present study showed that around $70 \%$ of respondents identified the criterion of animal welfare as very important in their buying decision, similar to the results of Jiang et al. (2021) where animal welfare is an important factor for liking milk during tasting.
Findings of the present study contribute to a better understanding of differentiation in the German fresh milk market and delivered an answer to the question, are different buying decisions primarily driven by credence-good attributes, such as organic or pasturebased versus conventional, or is there evidence that experience-related product attributes (such as taste and overall assessment) also explain consumers' buying decisions to some extent? In other studies, it was detected that consumer differentiation is influenced by perceptions and beliefs for a specific milk type (Harwood and Drake, 2020). Comparing to all studied milk types, the most preferred milk in the present study was organic milk from the brand Hamfelder Hof. Around $62 \%$ of respondents preferred organic milk to all other types of milk, and around $60 \%$ of respondents preferred Hamfelder Hof to other brands. This finding can be explained that organic milk has a particularly positive image and represents various sustainable credence-good attributes, even though this can lead to a higher final milk price. The results of this study did not investigate the effect on health of organic milk, but the respondents in this study preferred this type of milk because they were looking for healthier and environmentally friendly alternatives to conventional food (Chang et al., 2011). Thus, dairy companies can benefit from this belief that organic milk is healthier and use this in their advertising strategies and promotion of dairy products. Other studies detected that organic labeling on the package of chocolate milk has no significant effect on its purchasing decision (Kim et al., 2013). Moreover, the present study found that consumers have a greater preference for organic milk than other milk types what can be explained that its positive image is usually associated with a healthy lifestyle. In addition, around 67 and $70 \%$ of respondents who would like to buy organic milk selected freshness and quality, respectively, as very important criteria in their milk buying decision.

For identifying the influence of nontaste factors (e.g., brand loyalty, brand image) on preferences, both blind and nonblind tests should be performed (Ghose and Lowengart, 2001). In a fact, both types of tests were conducted in the present study, followed by the measurement of differences in milk taste evaluations between blind and nonblind tastings. When comparing the milk samples' blind and nonblind taste assessments, all the respondents' evaluations were statistically significantly different from each other. This finding may mean that the respondents were influenced by the milk packaging or credence image and rated the taste of the same type of milk differently under the blind and nonblind tastings. Without showing the packaging to the respondents, they were unable to identify the type of 
milk they were drinking, but anyway the taste evaluations differed between the blind and nonblind tastings. Thus, packaging, brand, image, and credence-good attributes can play an important role in the evaluation of taste, and therefore, in the buying decisions for different milk types. However, only $15 \%$ of consumers chose packaging design as an important criterion in their buying decision, and it appears that consumers are more affected by the packaging and its design than they realize. However, some researchers could assert that there are also other important factors that compel consumers to purchase different types of milk (Delley and Brunner, 2020). Other studies found that brand affects purchasing decisions for milk (chocolate milk) more consistently than a subjective total assessment of the same type of milk (Kim et al., 2013).

A potential explanation for the finding that female respondents buy more organic milk may be that women use milk more often in connection with child nutrition than men, and that is why women care more about healthy and sustainable types of milk, which is the image organic milk appears to have. This positive image of organic milk is probably more attractive for women than for men. Women are probably more sensitive to the credence-good attribute of organic milk and believe that organic milk consumption has more health benefits than the consumption of another milk type. Similar beliefs for pasture-raised milk were depicted by Kühl et al. (2017), which are related to assumption that pasture-raised milk has better taste and higher health value.

Some studies showed that milk buying decisions are positively affected by information on product labels (e.g., Hoque et al., 2018), whereas the results of the present study demonstrated that there were more positive buying decisions for fresh whole milk, organic milk, and pasture milk when the respondents were shown the packaging (nonblind tasting). However, from the results of the present study, the exception was only long-life milk, because just around $15 \%$ of respondents decided positively to buy this type of milk sometimes in the future under the nonblind tasting, whereas this share was $37 \%$ under the blind tasting. In addition, other researchers found out that under blind tasting less buying decisions for chocolate organic milk were met in contrast to the nonblind tasting (Kim et al., 2013).

Some studies revealed that "uncompromising consumers" (24\% of the sample) select milk for buying based on taste, fat content, shelf life, packaging size, and price, whereas "locavores" (56\% of the sample) prefer more fresh milk than long-life milk (UHT) and are in general interested in organic foods (Delley and Brunner, 2020).
At the same time, another group of consumers "indifferent consumers" (20\% of the sample) do not show interest for organic food and include mostly men and young people (Delley and Brunner, 2020), whereas in the present study it was found out that women tend to prefer organic milk more than men.

In contrast to previous studies, this study did not evaluate fat content or investigate price issues, but instead examined the potential impact of brands or credence-good effects. The present study results can be used to provide information to consumers, dairy companies, and milk producers about the nature and origin of preferences for different types of milk. These results can contribute to building and developing successful advertising and marketing strategies for dairy companies based on an awareness of the factors influencing buying decisions, as well as the preferences of milk consumers.

The limitations of the present study encompass some of the difficulties of assessing 4 different milk types with respondents in blind and nonblind tasting sessions. Although water and crackers were offered between tastings, there were 8 milk samples for blind and nonblind tastings to evaluate, as well as 6 samples for paired preference tests in total, which may have affected the respondents' perception of taste. In addition, $17.3 \%$ of respondents usually preferred milk with a fat content between 1.5 and $1.8 \%$ rather than the whole milks offered during the experiment, and this might have influenced their taste perceptions and stated evaluations. An additional limitation of the present study can be seen in the fact that $61.7 \%$ of respondents self-reported to prefer organic milk, and therefore, their taste perceptions during the (nonblind) tasting experiment could be influenced by their preferences in favor of organic milk.

An investigation of consumers' preferences for different fat contents in milk, comparing the preferences for skim milk and high-fat milk, an examination of price differences and their impact on buying decisions, as well as blind and nonblind tastings of plant-based milk can be subjects of future research.

\section{CONCLUSIONS}

It appears that pasture-based milk, organic milk and fresh whole milk have a better image, and long-life (UHT) milk has a worse image than the actual blinded taste preferences would suggest. The taste of almost all milk types was evaluated significantly different from each other when comparing the results of blind tasting and nonblind tasting. Factors such as taste, total assessment of the milk, and income are most important 
in the consumers' buying decisions under blind and nonblind tasting for almost all milk types. In summary, there were significant differences in taste of the milk types tested in this study. Income significantly influences buying decisions for almost all milk types, except pasture milk under blind tasting and organic milk under blind and nonblind tasting. Thus, product differentiation according to credence-good attributes will continue to play a role as people's incomes rise. Packaging design will be important.

\section{ACKNOWLEDGMENTS}

This research did not receive any specific grant from funding agencies in the public, commercial or not-forprofit sectors. No explicit approval of institutional review board was required. The study is a nonintrusive consumer research. The authors have worked on the manuscript during their regular working time as employed researchers at Kiel University and University of Hohenheim, respectively. The authors are grateful to 2 anonymous reviewers and the editor, and also to Professor Loy and members of the Department of Agricultural Economics in Kiel for valuable comments on earlier versions of the manuscript. The authors have not stated any conflicts of interest.

\section{REFERENCES}

Andersen, L. M., and S. Smed. 2013. What is it consumers really want, and how can their preferences be influenced? The case of fat in milk. Empir. Econ. 45:323-347. https://doi.org/10.1007/s00181 $-012-0619-8$.

Bakke, A. J., C. V. Shehan, and J. E. Hayes. 2016. Type of milk typically consumed, and stated preference, but not health consciousness affect revealed preferences for fat in milk. Food Qual. Prefer. 49:92-99. https://doi.org/10.1016/j.foodqual.2015.12.001.

Bimbo, F., A. Bonanno, X. Liu, and R. Viscecchia. 2016. Hedonic analysis of the price of UHT-treated milk in Italy. J. Dairy Sci. 99:1095-1102. https://doi.org/10.3168/jds.2015-10018.

Celik Ates, H. C., and M. Ceylan. 2010. Effects of socio-economic factors on the consumption of milk, yoghurt, and cheese: Insights from Turkey. Br. Food J. 112:234-250. https://doi.org/10.1108/ 00070701011029110.

Chang, C. H., N. H. Hooker, E. Jones, and A. Sam. 2011. Organic and conventional milk purchase behaviors in Central Ohio. Agribusiness 27:311-326. https://doi.org/10.1002/agr.20269.

Chapman, K. W., and K. J. Boor. 2001. Acceptance of $2 \%$ ultrapasteurized milk by consumers, 6 to 11 years old. J. Dairy Sci. 84:951-954. https://doi.org/10.3168/jds.S0022-0302(01)74553-5.

Chavan, R. S., R. Sehrawat, V. Mishra, and S. Bhatt. 2016. Milk: Processing of milk. Pages 729-735 in Encyclopedia of Food and Health. https://doi.org/10.1016/B978-0-12-384947-2.00464-5.

Chimboza, D., and E. Mutandwa. 2007. Measuring the determinants of brand preference in a dairy product market. Afr. J. Bus. Manag. $1: 230-237$.

Chung, S. J. 2009. Effects of milk type and consumer factors on the acceptance of milk among Korean female consumers. J. Food Sci. 74:S286-S295. https://doi.org/10.1111/j.1750-3841.2009.01224.x.

Colonna, A., C. Durham, and L. Meunier-Goddik. 2011. Factors affecting consumers' preferences for and purchasing decisions re- garding pasteurized and raw milk specialty cheeses. J. Dairy Sci. 94:5217-5226. https://doi.org/10.3168/jds.2011-4456.

de Graaf, S., E. J. Van Loo, J. Bijttebier, F. Vanhonacker, L. Lauwers, F. A. Tuyttens, and W. Verbeke. 2016. Determinants of consumer intention to purchase animal-friendly milk. J. Dairy Sci. 99:83048313. https://doi.org/10.3168/jds.2016-10886.

Delarue, J., B. Lawlor, and M. Rogeaux, eds. 2014. Rapid Sensory Profiling Techniques: Applications in New Product Development and Consumer Research. Elsevier.

Delley, M., and T. A. Brunner. 2020. A segmentation of Swiss fluid milk consumers and suggestions for target product concepts. J. Dairy Sci. 103:3095-3106. https://doi.org/10.3168/jds.2019-17325.

Dimitri, C., and K. M. Venezia. 2007. Retail and Consumer Aspects of the Organic Milk Market. USDA Economic Research Service.

Ghose, S., and O. Lowengart. 2001. Taste tests: Impacts of consumer perceptions and preferences on brand positioning strategies. J. Targeting. Meas. Anal. Marketing. 10:26-41. https://doi.org/10 $.1057 /$ palgrave.jt.5740031.

GOMPMR. 2018. Global Organic Milk Production Market Report, KPMG. Accessed Feb. 07, 2021. https://assets.kpmg/content/ $\mathrm{dam} / \mathrm{kpmg} / \mathrm{au} / \mathrm{pdf} / 2018 /$ global-organic-milk-production-market -report.pdf.

Halim, J., X. Zhang, and M. O'Mahony. 2020. Paired preference tests and placebo placement: 1 . Should placebo pairs be placed before or after the target pair? Food Res. Int. 136:109344. https://doi.org/ 10.1016/j.foodres.2020.109344.

Harwood, W. S., and M. A. Drake. 2018. Identification and characterization of fluid milk consumer groups. J. Dairy Sci. 101:8860-8874. https://doi.org/10.3168/jds.2018-14855.

Harwood, W. S., and M. A. Drake. 2020. The influence of automatic associations on preference for milk type. J. Dairy Sci. 103:1121811227. https://doi.org/10.3168/jds.2020-19037.

Hill, A. R. 1988. Quality of ultra-high-temperature processed milk. Food Technol. (Chicago) 42:92-97.

Hoque, M. Z., J. Xie, and S. Nazneen. 2018. Effect of labelled information and sensory attributes on consumers' intention to purchase milk. South Asian J. Bus. Stud. 7:265-286. https://doi.org/10 .1108/SAJBS-02-2018-0021.

Jiang, R., C. Sharma, R. Bryant, M. S. Mohan, O. Al-Marashdeh, R. Harrison, and D. D. Torrico. 2021. Animal welfare information affects consumers' hedonic and emotional responses towards milk. Food Res. Int. 141:110006. https://doi.org/10.1016/j.foodres.2020 .110006 .

Joubert, J. P., and J. Poalses. 2012. What's in a name? The effect of a brand name on consumers' evaluation of fresh milk. Int. J. Consum. Stud. 36:425-431. https://doi.org/10.1111/j.1470-6431 .2011.01065.x.

Kim, M. K., K. Lopetcharat, and M. A. Drake. 2013. Influence of packaging information on consumer liking of chocolate milk. J. Dairy Sci. 96:4843-4856. https://doi.org/10.3168/jds.2012-6399.

Kühl, S., B. Gassler, and A. Spiller. 2017. Labeling strategies to overcome the problem of niche markets for sustainable milk products: The example of pasture-raised milk. J. Dairy Sci. 100:5082-5096. https://doi.org/10.3168/jds.2016-11997.

Kurajdová, K., J. Táborecká-Petrovičová, and A. Kaščáková. 2015. Factors influencing milk consumption and purchase behavior-Evidence from Slovakia. Procedia Econ. Finance 34:573-580. https:// doi.org/10.1016/S2212-5671(15)01670-6.

Liming, N. E. 1966. Consistency of a trained taste panel. J. Dairy Sci. 49:628-630. https://doi.org/10.3168/jds.S0022-0302(66)87921-3.

Liu, H., A. J. Grosvenor, X. Li, X. L. Wang, Y. Ma, S. Clerens, J. M. Dyer, and L. Day. 2019. Changes in milk protein interactions and associated molecular modification resulting from thermal treatments and storage. J. Food Sci. 84:1737-1745. https://doi.org/10 $.1111 / 1750-3841.14663$.

Papafotikas, I., D. Chatzoudes, and I. Kamenidou. 2014. Purchase decisions of Greek consumers: An empirical study. Procedia Econ. Finance 9:456-465. https://doi.org/10.1016/S2212-5671(14)00047 $-1$. 
Paul, J., and J. Rana. 2012. Consumer behavior and purchase intention for organic food. J. Consum. Mark. 29:412-422. https://doi .org/10.1108/07363761211259223.

Penfield, M. P., and A. M. Campbell. 1990. Milk and milk products. Pages 162-183 in Experimental Food Science. 3rd ed. Academic Press. https://doi.org/10.1016/B978-0-12-157920-3.50012-0.

Rosenberg, M. 2022. UHT sterilized milks. Pages 477-488 in Encyclopedia of Dairy Sciences. 3rd ed. https://doi.org/10.1016/B978-0 -12-818766-1.00118-5.

Tuorila, H. 1987. Selection of milks with varying fat contents and related overall liking, attitudes, norms and intentions. Appetite 8:1-14. https://doi.org/10.1016/S0195-6663(87)80022-3.

Vargas-Bello-Pérez, E., I. Faber, J. S. Osorio, and S. Stergiadis. 2020 Consumer knowledge and perceptions of milk fat in Denmark, the United Kingdom, and the United States. J. Dairy Sci. 103:41514163. https://doi.org/10.3168/jds.2019-17549.

Villalobos-Chaparro, S., E. Salas-Muñóz, N. Gutiérrez-Méndez, and G. V. Nevárez-Moorillón. 2018. Sensory profile of Chihuahua cheese manufactured from raw milk. Int. J. Food Sci. 2018:8494105. https: //doi.org/10.1155/2018/8494105.

Villegas-Ruiz, X., O. Angulo, and M. O'Mahony. 2008. Paired preference "placebo" tests with "identical" stimuli: Does introducing graded preference responses affect the frequency of "No Prefer- ence" responses? J. Sens. Stud. 23:439-449. https://doi.org/10 $.1111 / \mathrm{j} .1745-459 X .2008 .00164 . x$.

Weiss, S., E. Davis, A. C. Wojtanowski, G. D. Foster, K. Glanz, and A. Karpyn. 2015. Consumer taste tests and milk preference in lowincome, urban supermarkets. Public Health Nutr. 18:1419-1422. https://doi.org/10.1017/S1368980014001980.

Young, N. D., M. Drake, K. Lopetcharat, and M. R. McDaniel. 2004. Preference mapping of Cheddar cheese with varying maturity levels. J. Dairy Sci. 87:11-19. https://doi.org/10.3168/jds.S0022 -0302(04)73136-7.

Zhang, X., J. Halim, S. Wichchukit, M. O'Mahony, and M. J. Hautus. 2016. Paired preference tests: A signal detection based analysis with separate d' values for segmentation. J. Sens. Stud. 31:481491. https://doi.org/10.1111/joss.12238.

\section{ORCIDS}

Svetlana Kresova @ ittps://orcid.org/0000-0002-8464-5142

Daijana Gutjahr (ㄴ) https://orcid.org/0000-0002-8491-8892

Sebastian Hess $\odot$ https://orcid.org/0000-0002-4597-7654 